\title{
IMPLEMENTASI UNIFIED MODELLING LANGUAGE PADA SISTEM INFORMASI NASGOR DELIVERY BERBASIS WEB
}

\author{
Salman Alfarizi ${ }^{1^{*}}$, Alif Rizqi Mulyawan ${ }^{2}$, Deni Gunawan ${ }^{3}$, Riska Aryanti ${ }^{4}$ \\ 1,2,3,4 Fakultas Teknik dan Informatika, Universitas Bina Sarana Informatika \\ 'Email : salman.slz@bsi.ac.id \\ 2Email : alif.aqm@bsi.ac.id \\ ${ }^{3}$ Email : deni.dee@bsi.ac.id \\ Email : riska.rts@bsi.ac.id
}

\begin{abstract}
Abstrak
Saat ini penjualan dan promosi usaha melalui media online sudah terbiasa dilakukan oleh sebagian besar masyarakat kita melalui media sosial seperti Watssapp, Facebook, Instagram. Tujuannya tidak lain adalah untuk menarik sebanyak-banyaknya pelanggan. Di balik penggunaan media tersebut ada pekerjaan-pekerjaan yang masih akan dilakukan secara konvensional. Seperti merekap data pesanan mana yang masih berstatus proses dan yang sudah berstatus sudah diantarkan dalam rekapan kertas, hingga mengelola data pelanggan, data laporan penjualan. Berangkat dari permasalahan yang ada maka kami mengusulkan pembuatan sistem informasi nasgor delivery yang dapat menjadikan proses bisnis bisa lebih tertata dan terkelola dengan baik. Metode Pengembangan sistem yang digunakan yaitu model waterfall yang terbagi menjadi lima tahapan yaitu perencanaan sistem, desain sistem, penulisan kode, pengujian sistem, pemeliharaan web. Rancang bangun website menggunakan bahasa php dengan database mysql. Pemodelan sistem untuk alur proses bisnis menggunakan UML (Unified Modelling Language). Hasil dari perancangan Sistem ini adalah Website Nasgor Delivery dimana terdapat dua hak akses yaitu admin dan user. Admin yang dapat mengelola data pesanan, data pelanggan, data laporan, mencetak struk pembayaran, sedangkan user dapat melihat menu makanan, memesan menu makanan, melihat kontak rumah makan dan melihat status pemesanan.
\end{abstract}

Kata Kunci: Website, Sistem Informasi Delivery, Pemesanan

\section{Abstract}

Nowadays, online media sales and promotions are used to most communities through social media such as watssapp, facebook, instagram. The goal is to attract as many customers as possible. Behind such media use are jobs that will still be done conventionally. Such as containing data which order is still processed and which is already delivered on a paper realignment, To manage customer data, sales reports data. Then, on the basis of the problem, we move for nasgor delivery information system, which makes business process more manageable and well managed. The system development method used is the waterfall model, which divides into the five stages of system planning, system design, code writing, system testing, web maintenance. PHP design websites with mysql databases. Modeling systems for the pipeline of business processes using UML (Unified Modelling Language). The result of the design of this system is a nasgor delivery website where there are two privileges: admin and user. Admin can manage order data, customer data, report data, print a receipt, while the user can see the menu, order a menu, see the restaurant contacts and see the reservation status.

Keywords: Website, Delivery Information System, Ordering 


\section{Pendahuluan}

Dalam kemajuan dan perkembangan teknologi informasi saat ini yang sangat pesat, terutama di dalam cara mempromosikan produk secara online, website tidak hanya mengacu pada tujuannya saja, melainkan pada unsur seni dan keindahan pada desain sehingga terlihat menarik perhatian para pengguna internet pada umumnya. Website biasanya memiliki gagasan atau tema yang mengajak konsumennya melakukan sesuatu seperti misalnya mencari informasi tentang perusahaan, maka informasi yang diperoleh adalah mengenai informasi profile perusahaan tersebut.

Pada dasarnya keberhasilan perusahaan dalam menghadapi tantangan erat saat ini terletak dalam kemampuan perusahaan dalam melakukan pengolahan informasi perusahaan tersebut, selain itu juga akan memberikan dampak sebagai akibat dalam menghadapi persaingan perdagangan bebas, maka industri atau perusahaan harus dapat meningkatkan sistem informasi teknologi agar mempermudah dalam proses kerja. Apabila suatu perusahaan telah menggunakan teknologi yang sekarang untuk kegiatannya maka akan dapat dikatakan pengolahan kegiatan dapat dilaksanakan dengan maksimal.

Nasi Goreng Delivery adalah Pondok Nasi Goreng yang bergerak dibidang kuliner. pondok nasi goreng ini dalam pemasarannya menggunakan media sosial. Di balik penggunaan media tersebut ada pekerjaan-pekerjaan yang masih akan dilakukan secara konvensianal seperti merekap data pesanan mana yang masih berstatus proses dan yang sudah berstatus sudah diantarkan dalam rekapan kertas, hingga mengelola data pelanggan, data laporan penjualan. diperlukan suatu Pengolahan data yang lebih canggih dengan menggunakan komputer. Hal ini diperlukan untuk merealisasikan perolehan informasi yang cepat, rapih, dan tepat waktu dan website dapat membantu penyampaian informasi produk dan harga secara detail kepada konsumen[1]. Berangkat dari permasalahan yang ada maka kami mengusulkan pembuatan sistem informasi nasgor delivery yang dapat mengelola data pesanan, data pelanggan, data laporan sehingga proses bisnis bisa lebih tertata dan terkelola dengan baik.
Dalam pengembangan sistemnya akan menggunakan Metode Waterfall karena Berdasarkan penelitian sebelumnya sistem informasi dengan menerapkan desain waterfall mampu memberikan solusi dari permasalahan yang dihadapi seperti penerapan sistem informasi simpan pinjam pada PT. Chiyoda integre Indonesia [2], Sistem Informasi Pengelolaan penjualan Catering [3], Sistem Informasi dalam booking perekaman EKTP[4]. Metode waterfall pada sistem informasi Truliving[5].

\section{Tinjauan Pustaka}

\section{Website dan Internet}

Website merupakan sebuah media yang menyajikan sebuah informasi melalui metode tautan atau disebut (Hyperlink) yang dapat memudahkan pengguna mengkases berbagai informasi melalui internet[6].

"Sejarah masuknya internet di indonesia dimulai pada awal tahun 1990-an. Saat itu jaringan internet di indonesia lebih dikenal sebagai paguyuban network, dimana semangat kerjasama, kekeluargaan dan gotong royong sangat hangat dan terasa diantara pelakunya".

Istilah internet berasal dari bahasa latin inter yang berarti antara. Secara kata perkata internet berarti jaringan atau penghubung. Memang itulah fungsinya, internet menghubungkan berbagai jaringan yang tidak saling bergantungan pada satu sama lain sedemikian rupa, sehingga mereka dapat berkomunikasi[7].

\section{Pengertian Mysql}

MySQL merupakan sebuah perangkat lunak Manajemen Sistem Basis data atau lebih kita kenal dengan nama Database Management System (DBMS) yang bersifat multi-user dan multithread. Berisikan fiturfitur seperti Relational Database System dan Arsitektur Client-server dengan bahasa perintah SQL (structured Query Language). "MySQL adalah sebuah system manajemen database. Database adalah sekumpulan data yang terstruktur" [8]. 


\section{Database}

Database atau Basis Data merupakan kumpulan data dimana data tersebut saling berelasi. Data dalam dunia nyata adalah fakta tentang objek, orang yang dinyatakan dalam bentuk nilai[9]

\section{Entity Relationship Diagram (ERD)}

Pengertian Entity Relationship Diagram (ERD) adalah pemodelan entitas yang saling berelasi yang masing-masing entitas memiliki atribut-atribut yang mempresentasikan fakta dalam dunia nyata[9].

\section{Logical Structured Diagram (LRS)}

Logical Record Structure digambarkan dalam kotak persegi panjang yang didalamnya memuat alur logic sebuah record[9].

\section{Bahasa Pemrograman PHP}

PHP (Hypertext Preprocessor) adalah akronim dari Hypertext Preprocessor, yaitu suatu bahasa pemrograman berbasiskan kode-kode (script) yang digunakan untuk mengolah suatu data dan mengirimkannya kembali ke web browser menjadi kode HTML (Hypertext Markup Language).

PHP (Hypertext Preprocessor)

berupa bahasa pemrograman web yang bersifat opensource dan berbasis teks. MySQL (My Structure Query Language) merupakan program database server sebagai tempat menyimpan dan mengolah data.

Kode PHP (Hypertext Preprocessor) mempunyai ciri-ciri khusus, yaitu:

1. Hanya dapat dijalankan menggunakan web server, contohnya Apache.

2. Kode PHP (Hypertext Preprocessor) dapat digunakan dan dijalankan di web server.

3. Kode PHP (Hypertext Preprocessor) dapat digunakan untuk mengakses database, seperti: MySQL (My Structure Query Language), Oracle, dan lain-lain.

4. Merupakan software yang bersifat open source.

5. Gratis untuk di-download dan digunakan.

6. Memiliki sifat multiplatform, artinya dapat dijalankan menggunakan sistem operasi apapun, seperti: Linux, Unix, Windows, dan lain-lain[10].

\section{Unified Modelling Language (UML)}

"UML (Unified Modeling Language) adalah model pengembangan perangkat lunak yang berorientasi pada objek. Modelling digunakan untuk bagaimana masalah bisa disederhanakan sihingga mudah untuk dipahami[11].

\section{Usecase Diagram}

"Use Case Diagram dipakai untuk menggambarkan relasi antara sistem dan sistem eksternal dan user, dengan kasus yang disesuaikan dengan langkah-langkah yang telah ditentukan"[12].

\section{Activity Diagram}

Activity diagram merupakan sebuah diagram yang dapat digunakan untuk menggambarkan sebuah alur aktivitas use case atau proses bisnis secara berurutan[12].

\section{Metode Penelitian}

Dalam rangka pengumpulan data yang diperlukan penulis untuk bahan penulisan ini, maka penulis menggunakan beberapa metode yaitu:

1. Metode Pengembangan Perangkat lunak Metode yang digunakan pada pengembangan perangkat lunak ini menggunakan model waterfall yang terbagi menjadi lima tahapan, yaitu :

a. Perencanaan Sistem

(System

Planning/Analysis)

Tahapan ini biasanya melakukan perencanaan dan analisis terlebih dahulu sebelum mengerjakan web. Seperti perancangan sistem dan analisis, database 
dan tabel apa saja yang akan diambil, bagaimana flowchart atau alur sistemnya, membuat peta situs, membuat jadwal kerja, menumpulkan bahan, dan sebagainya. Proses ini bisa dianggap sebagai titik utama dari proses pengerjaan web[11].

\section{b. Desain Sistem (Desaigning)}

Pada tahapan ini biasanya Web Desainer dituntun untuk mahir dalam penggunaan software olah digital.

c. Penulisan Kode (Coding)

Tahapan ini merupakan tahapan proses yang paling lama memakan waktu dan paling sulit karena tahap ini berisi codingcoding yang harus dikerjakan oleh posisi yang berkaitan. Semua tidak akan berjalan tanpa ada tahap coding. Tahap coding biasanya disebut dengan istilah programmer.

d. Pengujian Sistem (Testing)

Seluruh sistem harus melewati tahap pengujian untuk menghindari adanya error. Jika error pada bagian sistem, program akan dikembalikan pada tahap sebelumnya. Namun jika error menunjukan pada sisi desaign berantakan dan sebagainya, maka program akan dikembalikan dua langkah sebelumnya, yaitu tahap Desaigning. Kemudian jika selesai, lakukan pengujian kembali.

\section{e. Pemeliharaan Web (Maintenance)}

Tahap ini merupakan pemeliiharaan web yang dilakukan ketika web sistem mengalami kerusakan.selain itu pada tahap ini jua dapat merubah atau menambah fitur.

\section{Teknik Pengumpulan Data}

Metode pengumpulan data yang digunakan dalam penelitian ini yaitu dengan menggunakan metode observasi, metode wawancara dan metode studi pustaka[13].

a. Metode wawancara

Penulis melakukan wawancara langsung pada sumber data yaitu beberapa karyawan Pondok Nasi Goreng, untuk mendapatkan informasi apa saja permasalahan yang dihadapi dan bagaimana cara alternatif permasalahannya.

\section{b. Metode Survei atau Observasi}

Penulis melakukan survei ke Pondok Nasi Goreng, untuk mengumpulkan data dengan prosedur-prosedur transaksi pemesanan yang sedang berlangsung.

\section{c. Studi Kepustakaan}

Metode studi pustaka (literature), penulis mengumpulkan data dari berbagai buku bacaan, yang erat kaitannya dengan tema penulisan artikel ini seperti buku-buku, jurnal-jurnal mengenai pembuatan website, pemrograman web, sehingga didapatkan dasar ilmiah yang kuat dalam penyusunan artikel ini.

\section{Hasil dan Pembahasan}

\section{Analisa Kebutuhan}

Dalam perancangan sebuah program perlu dilakukan proses analisa kebutuhan yang bertujuan untuk mencari dan menganalisa data tentang kebutuhan yang diperlukan pada sistem yang berjalan apakah masih terdapat kukarangan atau masalah yang dihadapi. Karena itu harus terdapat solusi yang dapat mengurangi ataupun menutup kekurangan dan masalah dari sistem yang telah ada. Analisa kebutuhan yang yang diperlukan terbagi menjadi dua bagian, antaralain:

\section{A. Kebutuhan Pengguna (User)}

Kebutuhan pengguna (user) merupakan aspek-aspek yang diperlukan pengguna (user) untuk dapat menjalakan sistem sesuai dengan kriteria yang butuhkan dengan tujuan mempermudah pengguna tersebut. Adapun kebutuhan pengguna yang diperlukan adalah:

1. User dapat melihat menu makanan

2. User dapat memesan menu makanan

3. User dapat melihat kontak rumah makan

4. User dapat melihat status pemesanan

B. Kebutuhan Sistem 
Kebutuhan sistem merupakan kemampuan, syarat atau kriteria yang harus ada atau dipenuhi oleh sistem, sehingga apa yang diinginkan pengguna (user) dari sistem dapat diwujudkan. adalah:

Adapun kebutuhan sistem yang diperlukan

1. Sistem dapat menampilkan data pemesanan

2. Sistem dapat mencetak struk pemesanan

3. Sistem dapat mencetak kwitansi pembayaran.

4. Sistem dapat mencetak laporan pemesanan perhari, perminggu dan perbulan.

\section{Desain}

\section{Usecase Diagram}

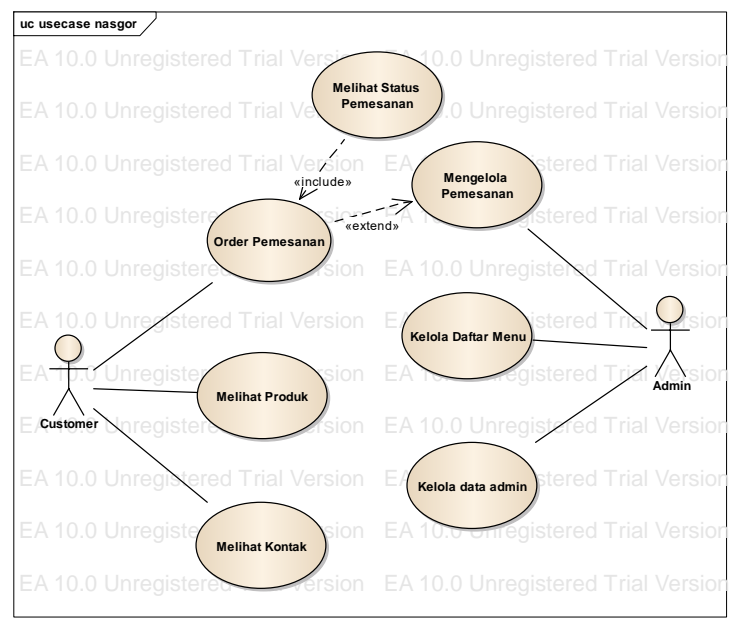

Gambar 1. Use Case Sisfo Delivery

Nasgor Sumber: Hasil Penelitian, 2020

\section{Activity Diagram}

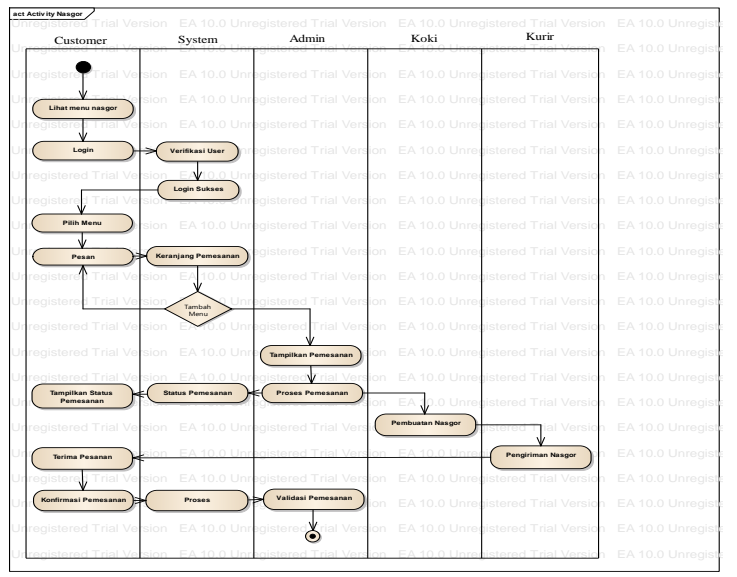

Gambar 2. Activity Diagram Sisfo

Delivery Nasgor Sumber: Hasil

Penelitian, 2020

\section{Perancangan Perangkat Lunak}

\section{Rancangan Dokumen}

Rancangan dokumen merupakan dokumen yang dibuat berdasarkan sistem yang dibuat sebagai lampiran pelengkap yang akan berguna untuk pengguna. Rancangan dokumen dari hasil perancangan web yang dirancang adalah sebagai berikut:

1. Nama Dokumen: Purchase Order

Fungsi : Sebagai bukti pemesanan nasi goreng

Sumber

Tujuan : Customer

Media : Kertas

Jumlah : 1 Lembar

Frekuensi : Setiap customer melakukan pemesanan nasi goreng

Bentuk : Lampiran A.1

2. Nama Dokumen : Laporan

Fungsi : Untuk mengetahui jumlah

semua

pemesanan yang telah dilakukan

Sumber

Tujuan : Pemilik

Media : Kertas

Jumlah $\quad: 1$ - 5 Lembar

Frekuensi : 1 Bulan sekali atau jika pemilik

meminta laporan

Bentuk : Lampiran A.2

\section{Rancangan Basis Data}

Perancangan basis data menghasilkan pemetaan tabel-tabel yang di gambarkan dengan ERD (Entity Relationship Diagram). 
A. Entity Relationship Diagram

B. Logical Record Structure

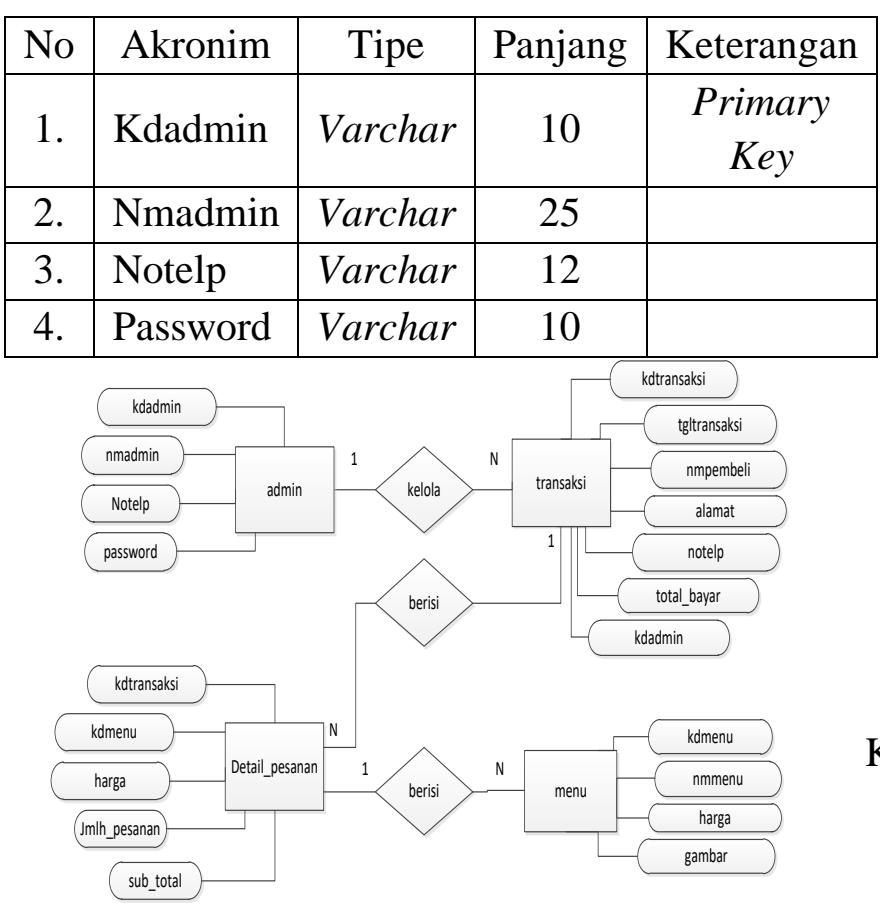

Gambar 3. ERD (Entity Relation Diagram)

Sumber : Hasil Penelitian, 2020

\section{Spesifikasi File}

Dalam web ini menggunakan satu buah Database dengan nama db_nasgor.sql dan didalamnya terdapat tabel-tabel sebagai entitas. Tabel-tabel tersebut sebagai berikut:

Spesifikasi File admin

Nama File : admin

Akronim : admin.ibd

Fungsi : Mengelola dan menyimpan data admin

Tipe File : File Master

Organisasi File: Index Sequential

Akses File : Random

Media : Harddisk

Panjang record: 57 Byte

Kunci Field : kdadmin

Software : MySQL

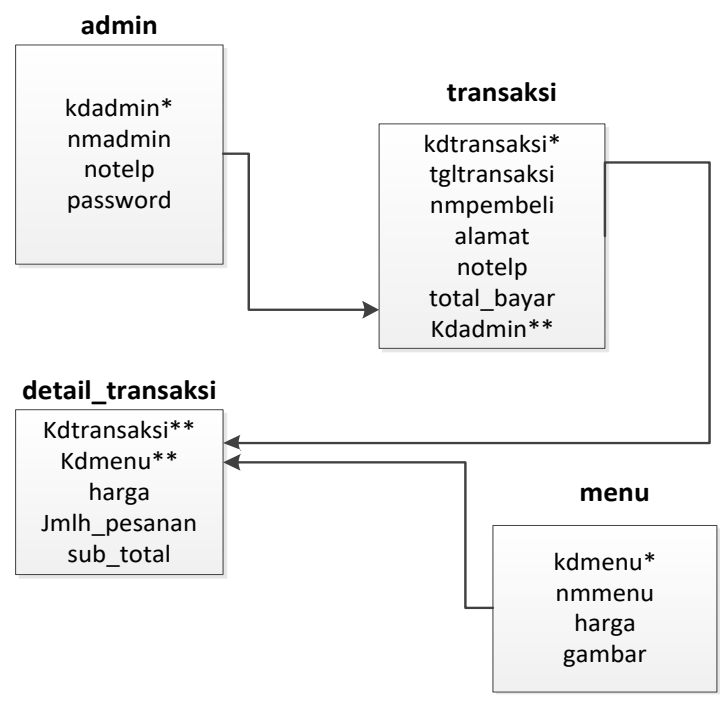

Keterangan : *Primary Key

**Foreign Key

Gambar 4.LRS (Logical Record Structure)

Sumber : Hasil Penelitian, 2020

Tabel 1. Spesifikasi File admin

Sumber : Hasil Penelitian, 2020

1. Spesifikasi File menu

Nama File : menu

Akronim : menu.ibd

Fungsi : Menyimpan dan mengelola

data menu nasi goreng

Tipe File : File Master

Organisasi File : Index Sequential

Akses File : Random

Media : Harddisk

Panjang record : 35 Byte

Kunci Field : kdmenu

Software : MySQL

Tabel 2. Spesifikasi File menu

\begin{tabular}{|c|l|c|c|l|}
\hline No & $\begin{array}{c}\text { Akroni } \\
\mathrm{m}\end{array}$ & Tipe & $\begin{array}{c}\text { Panja } \\
\mathrm{ng}\end{array}$ & \multicolumn{1}{|c|}{ Ket } \\
\hline 1. & $\begin{array}{l}\text { Kdmen } \\
\mathrm{u}\end{array}$ & $\begin{array}{c}\text { Varcha } \\
r\end{array}$ & 5 & $\begin{array}{l}\text { Primary } \\
\text { Key }\end{array}$ \\
\hline
\end{tabular}




\begin{tabular}{|c|l|c|l|l|}
\hline 2. & Nama & $\begin{array}{c}\text { Varcha } \\
r\end{array}$ & 30 & \\
\hline 3. & Harga & Double & & \\
\hline 4. & Gambar & Text & & \\
\hline
\end{tabular}

Sumber : Hasil Penelitian, 2020

2. Spesifikasi File transaksi

Nama File : transaksi

Akronim : transaksi.ibd

Fungsi :Mengelola data transaksi pemesanan nasi goreng

Tipe File : File Transaksi

Organisasi File: Index Sequential

Akses File : Random

Media : Harddisk

Panjang record: 65 Byte

Kunci Field : kdtransaksi

Software : MySQL

Tabel 3. Spesifikasi File transaksi

\begin{tabular}{|c|c|c|c|c|}
\hline No & Akronim & Tipe & $\begin{array}{l}\text { Panj } \\
\text { ang }\end{array}$ & Ket \\
\hline 1. & $\begin{array}{l}\text { Kdtransa } \\
\text { ksi }\end{array}$ & Varchar & 15 & $\begin{array}{c}\text { Primary } \\
\text { Key }\end{array}$ \\
\hline 2. & $\begin{array}{l}\text { tgltransa } \\
\text { ksi }\end{array}$ & Date & & \\
\hline 3. & $\begin{array}{l}\text { Nmpemb } \\
\text { eli }\end{array}$ & Varchar & 25 & \\
\hline 4. & Alamat & text & & \\
\hline 5. & notelp & Varchar & 15 & \\
\hline 6. & $\begin{array}{l}\text { Total_ba } \\
\text { yar }\end{array}$ & double & & \\
\hline 7. & kdadmin & Varchar & 10 & $\begin{array}{l}\text { Foreign } \\
\text { Key }\end{array}$ \\
\hline
\end{tabular}

Sumber : Hasil Penelitian, 2020

3. Spesifikasi File detail transaksi

Nama File : detail_transaksi

Akronim : detail_transaksi.ibd

Fungsi : Menyimpan data rincian

pemesanan pernomer transaksi

Tipe File : File Transaksi
Organisasi File: Index Sequential

Akses File : Random

Media : Harddisk

Panjang record : 31 Byte

Kunci Field : kdtransaksi

Software : MySQL

Tabel 4. Spesifikasi File detail transaksi

\begin{tabular}{|c|l|c|c|l|}
\hline No & Akronim & Tipe & $\begin{array}{c}\text { Pa } \\
\text { nja } \\
\text { ng }\end{array}$ & $\begin{array}{c}\text { Keterang } \\
\text { an }\end{array}$ \\
\hline 1. & $\begin{array}{l}\text { Kdtransa } \\
\text { ksi }\end{array}$ & Varchar & 15 & $\begin{array}{l}\text { Foreign } \\
\text { Key }\end{array}$ \\
\hline 2. & kdmenu & Varchar & 5 & $\begin{array}{l}\text { Foreign } \\
\text { Key }\end{array}$ \\
\hline 3. & harga & Double & & \\
\hline 4. & $\begin{array}{l}\text { jmlh_pes } \\
\text { anan }\end{array}$ & Integer & 11 & \\
\hline 5. & sub_total & Double & & \\
\hline
\end{tabular}

Sumber : Hasil Penelitian, 2020

\section{Spesifikasi Sistem Komputer}

Untuk memperoleh kemampuan yang optimal dalam pengolahan data diperlukan aspek dasar yaitu perangkat keras (Hardware) dan perangkat lunak (Software) yang saling berkaitan satu dengan lainnya sehingga tidak dapat dipisahkan, karena suatu sistem komputerisasi tidak akan berjalan tanpa ada salah satu aspek tersebut. Perangkat lunak dan perangkat keras harus dapat menunjukan kerja yang baik dan sesuai dengan yang diharapkan.

\section{Spesifikasi Perangkat Keras}

Perangkat keras (hardware) adalah serangkaian unsur-unsur yang terdiri dari beberapa perangkat keras yang membentuk suatu sistem komputer yang digunakan untuk mengoperasikan proses kerja pemakai.

Penulis mengusulkan untuk menggunakan perangkat keras sesuai dengan kemampuan, tanpa harus menggunakan tipe tertentu dengan harga yang lebih mahal. Namun disesuaikan dengan kebutuhan program aplikasi dan peket program yang dirancang. Spesifikasi perangkat 
keras yang diusulkan sebagai berikut:
a. Monitor : 16 "
b. Proccessor : Core2 Duo @2,00 GHz or Higher
c. Memory : $1 \mathrm{~GB}$ (Minimum)
d. Harddisk : $80 \mathrm{~GB}$
e. Keyboard : 102 Keys
f. Printer : Ink Jet
g. Mouse : USB atau $P S / 2$

2. Spesifikasi Perangkat Lunak

Bagian penting lain yang mendukung program adalah perangkat lunak (software) yang digunakan dalam mengeksekusi program aplikasi serta sistem operasi yang akan digunakan untuk menjalankan program tersebut. Sistem operasi ini berfungsi untuk mengidentifikasi dan menyiapkan aplikasi program sehingga tata kerja seluruh peralatan komputer dapat terkontrol.

Perangkat lunak yang dibutuhkan untuk menjalankan aplikasi program administrasi zakat ini adalah :

\section{Sistem operasi}

Windows $7 \times 86$ or Higher

\section{Bahasa pemrograman}

PHP, Java Script, Css, MySQL

\section{Program atau software pendukung}

\section{Xampp and Sublime}

\section{Implementasi}

1. Halaman Login Admin

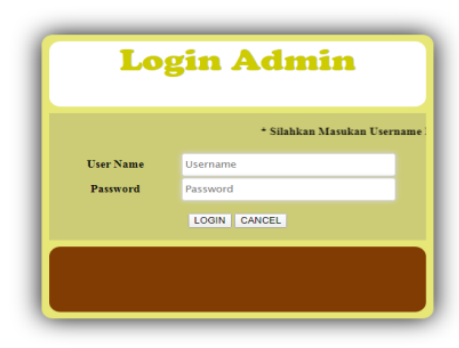

Gambar 5. Halaman Login Admin

Sumber : Hasil Penelitian, 2020
2. Halaman Utama Admin

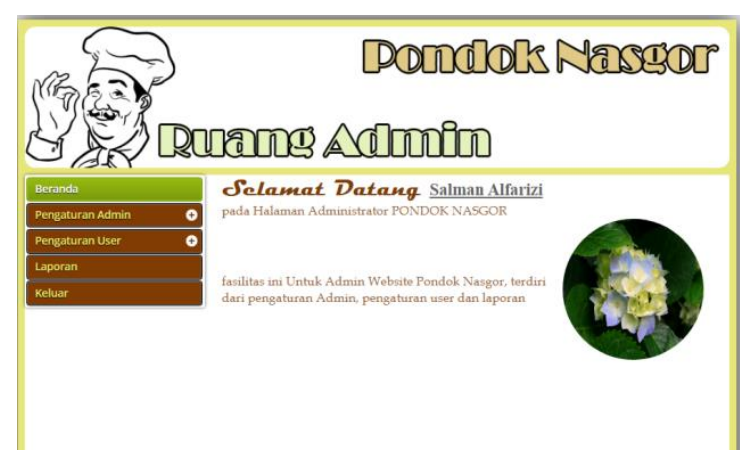

Gambar 6. Halaman Utama Admin

Sumber : Hasil Penelitian, 2020

3. Halaman Utama Pembeli

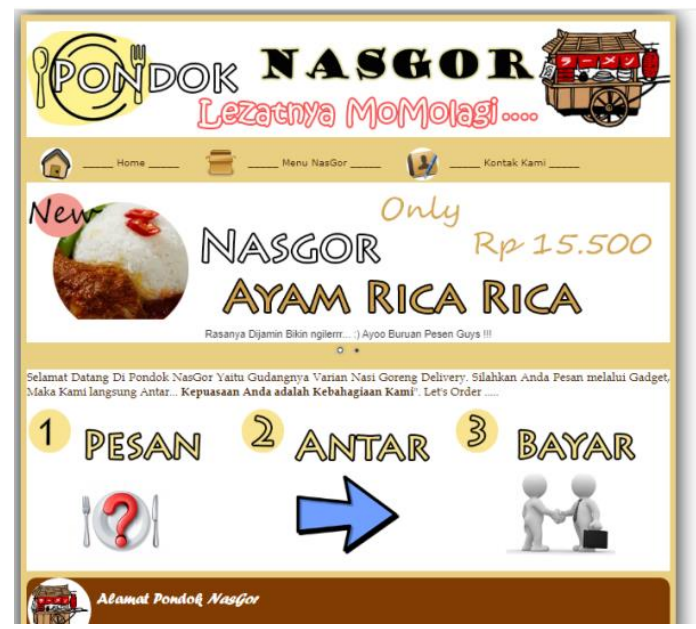

Gambar 7. Halaman Utama Pembeli

Sumber : Hasil Penelitian, 2020

4. Halaman Daftar Menu

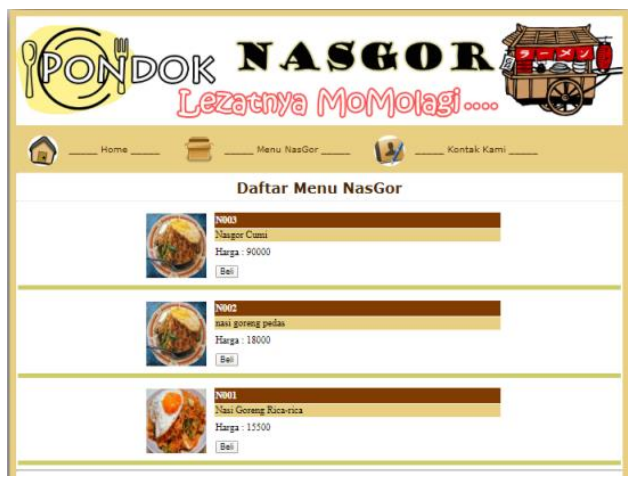

Gambar 8. Halaman Daftar Menu Sumber : Hasil Penelitian, 2020 


\section{Testing}

Form Login Admin

Tabel 6.Hasil Pengujian Black Box Testing Form Login Admin

Sumber : Hasil Penelitian, 2020

\begin{tabular}{|c|c|c|c|c|c|}
\hline $\begin{array}{l}\mathbf{N} \\
\mathbf{0}\end{array}$ & $\begin{array}{c}\text { Skenar } \\
\text { io } \\
\text { Penguj } \\
\text { ian }\end{array}$ & $\begin{array}{l}\text { Test } \\
\text { Case }\end{array}$ & $\begin{array}{r}\text { Ha } \\
\text { sil } \\
\text { ya } \\
\text { ng } \\
\text { dih } \\
\text { ara } \\
\text { pk } \\
\text { an }\end{array}$ & $\begin{array}{l}\text { Ha } \\
\text { sil } \\
\text { Pe } \\
\text { ng } \\
\text { uji } \\
\text { an }\end{array}$ & $\begin{array}{l}\text { Kesim } \\
\text { pulan }\end{array}$ \\
\hline 1 & $\begin{array}{l}\text { Mengos } \\
\text { ongkan } \\
\text { semua } \\
\text { isian } \\
\text { data } \\
\text { login } \\
\text { pada } \\
\text { login } \\
\text { siswa, } \\
\text { lalu } \\
\text { mengkl } \\
\text { ik } \\
\text { tombol } \\
\text { 'login' }\end{array}$ & $\begin{array}{l}\text { Usern } \\
\text { ame: } \\
\text { (koso } \\
\text { ng) } \\
\text { Passw } \\
\text { ord: } \\
\text { (koso } \\
\text { ng) }\end{array}$ & $\begin{array}{l}\text { Sis } \\
\text { te } \\
\mathrm{m} \\
\text { aka } \\
\mathrm{n} \\
\text { me } \\
\text { nol } \\
\text { ak } \\
\text { aks } \\
\text { es } \\
\text { log } \\
\text { in }\end{array}$ & $\begin{array}{l}\text { Ses } \\
\text { uai } \\
\text { har } \\
\text { apa } \\
\text { n }\end{array}$ & Valid \\
\hline 2 & $\begin{array}{l}\text { Hanya } \\
\text { mengisi } \\
\text { Userna } \\
\text { me dan } \\
\text { passwo } \\
\text { rd } \\
\text { kosong, } \\
\text { lalu } \\
\text { mengkl } \\
\text { ik } \\
\text { tombol } \\
\text { 'login' }\end{array}$ & $\begin{array}{l}\text { Usern } \\
\text { ame: } \\
\text { (adm0 } \\
\text { 1) } \\
\text { Passw } \\
\text { ord: } \\
\text { (koso } \\
\text { ng) }\end{array}$ & $\begin{array}{l}\text { Sis } \\
\text { te } \\
\mathrm{m} \\
\text { aka } \\
\mathrm{n} \\
\text { me } \\
\text { nol } \\
\text { ak } \\
\text { aks } \\
\text { es } \\
\text { log } \\
\text { in }\end{array}$ & $\begin{array}{l}\text { Ses } \\
\text { uai } \\
\text { har } \\
\text { apa } \\
\text { n }\end{array}$ & Valid \\
\hline 3 & $\begin{array}{l}\text { Userna } \\
\text { me } \\
\text { kosong } \\
\text { dan } \\
\text { passwo } \\
\text { rd diisi, } \\
\text { lalu } \\
\text { mengkl }\end{array}$ & $\begin{array}{l}\text { Usern } \\
\text { ame: } \\
\text { (koso } \\
\text { ng) } \\
\text { Passw } \\
\text { ord: } \\
\text { (adm0 } \\
\text { 1) }\end{array}$ & $\begin{array}{l}\text { Sis } \\
\text { te } \\
\mathrm{m} \\
\text { aka } \\
\mathrm{n} \\
\mathrm{me} \\
\text { nol } \\
\text { ak }\end{array}$ & $\begin{array}{l}\text { Ses } \\
\text { uai } \\
\text { har } \\
\text { apa } \\
\text { n }\end{array}$ & Valid \\
\hline
\end{tabular}

\begin{tabular}{|c|c|c|c|c|c|}
\hline & $\begin{array}{l}\text { ik } \\
\text { tombol } \\
\text { 'login' }\end{array}$ & & $\begin{array}{l}\text { aks } \\
\text { es } \\
\text { log } \\
\text { in }\end{array}$ & & \\
\hline 4 & $\begin{array}{l}\text { Mengin } \\
\text { put } \\
\text { dengan } \\
\text { salah } \\
\text { satu } \\
\text { data } \\
\text { yang } \\
\text { benar } \\
\text { saja } \\
\text { benar, } \\
\text { lalu } \\
\text { klik } \\
\text { tombol } \\
\text { 'login' }\end{array}$ & $\begin{array}{l}\text { Usern } \\
\text { ame: } \\
\text { (adm0 } \\
\text { 1) } \\
\text { Passw } \\
\text { ord: } \\
\text { (pwd_ } \\
\text { aja) }\end{array}$ & $\begin{array}{l}\text { Sis } \\
\text { te } \\
\text { m } \\
\text { aka } \\
\text { n } \\
\text { me } \\
\text { nol } \\
\text { ak } \\
\text { aks } \\
\text { es } \\
\text { log } \\
\text { in }\end{array}$ & $\begin{array}{l}\text { Ses } \\
\text { uai } \\
\text { har } \\
\text { apa } \\
\text { n }\end{array}$ & Valid \\
\hline 5 & $\begin{array}{l}\text { Mengin } \\
\text { put } \\
\text { dengan } \\
\text { data } \\
\text { yang } \\
\text { benar, } \\
\text { lalu } \\
\text { 'login' }\end{array}$ & $\begin{array}{l}\text { Usern } \\
\text { ame: } \\
\text { (adm0 } \\
\text { 1) } \\
\text { Passw } \\
\text { ord: } \\
\text { (123) }\end{array}$ & $\begin{array}{l}\text { Sis } \\
\text { te } \\
\mathrm{m} \\
\text { aka } \\
\mathrm{n} \\
\text { me } \\
\text { ner } \\
\text { im } \\
\text { a } \\
\text { dan } \\
\text { bis } \\
\text { a } \\
\text { log } \\
\text { in } \\
\text { unt } \\
\text { uk } \\
\text { me } \\
\text { nga } \\
\text { kse } \\
\text { s }\end{array}$ & $\begin{array}{l}\text { Ses } \\
\text { uai } \\
\text { har } \\
\text { apa } \\
\text { n }\end{array}$ & Valid \\
\hline
\end{tabular}

\section{Kesimpulan}

Dari pembahasan yang telah penulis bahas di bab sebelumnya, mengenai permasalahan yang ada pada Pondok Nasi Goreng yang belum memiliki sarana informasi atau promosi berupa website,

sehingga semua informasi yang disampaikan yang berupa transaksi pesan antar nasi goreng masih terhambat untuk diterima oleh masyarakat, maka penulis dapat mengambil kesimpulan sebagai berikut: 
1. Dengan dibuatnya website ini akan mempermudah dalam penyampain informasi kepada masyarakat mengenai Pondok Nasi Goreng dengan cepat dan mudah dan Pengolahan data menjadi lebih efektif.

2. Pembuatan laporan, baik laporan transaksi Pondok Nasi Goreng, pengambilan Nasi Goreng, data pelanggan maupun data paket Nasi Goreng dapat diakses dengan cepat.

3. Dengan pembuatan website, pelanggan dapat melakukan order untuk antar jemput Nasi Goreng. Pelanggan juga dapat mengakses informasi mengenai Pondok Nasi Goreng kapanpun dan dimanapun.

\section{Saran} adalah :

Adapun saran yang penulis berikan

1. Penulis menyadari tampilan website yang dirancang masih belum maksimal, oleh karena itu akan lebih baik jika diadakan penambahan fasilitas lain agar website menjadi lebih lengkap.

2. Pengembangan website ini mengedepankan komputer dan internet sebagai alat bantunya, sehingga sumber daya manusia yang telah terlatih diperlukan dalam pengoperasiannya.

3. Lakukan pengecekan rutin dan lengkap terhadap keamanan jaringan untuk menghindari adanya ancaman dari pihak luar yang akan mengganggu atau melakukan pencurian data.

\section{Daftar Pustaka}

[1] S. Deni Gunawan, Dwi Puji Hastuti, Ria Andriani, "Sistem Informasi Penjualan Berbasis Web Pada Restoran Caki Cake Karawang," J. AKRAB JUARA, vol. 2018, no. 1-10, pp. 1-18, 2018.

[2] W. Apriliah, N. Subekti, T. Haryati, S. Informasi, and S. Pinjam, "PENERAPAN MODEL WATERFALL DALAM PERANCANGAN APLIKASI SISTEM INFORMASI SIMPAN PINJAM PADA KOPERASI PT . CHIYODA INTEGRE INDONESIA
KARAWANG," J. Interkom, vol. 14, no. 2, pp. 34-42, 2019.

[3] S. Alfarizi, A. R. Mulyawan, and H. Basri, "Rancang Bangun Sistem Informasi Penjualan Berbasis Web Dengan Pemanfaatan Uml (Unified Modelling Language) Pada Cv Harum Catering Karawang," Ijns.org Indones. J. Netw. Secur., vol. 7, no. 4, pp. 23025700, 2018.

[4] H. Basri, S. Alfarizi, A. R. Mulyawan, A. Wiguna, and I. Habiba, "Perancangan Sistem Informasi Booking Perekaman EKtp (Si Mbok) Berbasis Web," J. Pilar Nusa Mandiri, vol. 15, no. 1, pp. 69-76, 2019, doi: 10.33480/pilar.v15i1.103.

[5] W. Apriliah, "Metode Waterfall Pada Sistem Informasi Penjualan Truliving PT Duta Laserindo Metal Cikarang," Inf. Syst. Educ. Prof., vol. 3, no. 2, pp. 153162, 2019.

[6] D. Ardiansyah, W. Walim, G. Deni, and Fitriani Eka;, "RANCANG BANGUN SISTEM INFORMASI PENJUALAN PERLENGKAPAN TIDUR (SIPPAT) BERBASIS WEB PADA FORTUN BAROKAH KARAWANG Dian," $J$. Inkofar, vol. 1, no. 1, pp. 68-79, 2019.

[7] Yuhefizar, "10 Jam Menguasai Internet Teknologi dan Aplikasinya." PT Elex Media Komputindo, Jakarta, 2008.

[8] A. Solichin, "MySQL Dari Pemula Hingga Mahir," Univ. Budi Luhur, Jakarta, pp. 1-117, 2010.

[9] Kusrini, strategi perancangan dan pengelolaan basis data. C.V. Andi Offset, 2007.

[10] D. P. Oktaviani, "Menjadi Programmer Jempolan Menggunakan PHP." pp. 3144, 2010.

[11] A. Nugroho, "Rekayasa Perangkat Lunak Berorientasi Objek dengan Metode USDP," Rekayasa Perangkat Lunak Berorientasi Objek dengan Metode USDP. p. 318, 2010.

[12] J. Wilson and G. Morrisroe, "Systems analysis and design," Evaluation of Human Work, 3rd Edition. pp. 241-279, 2005, doi: 10.1201/9781420055948.pt2.

[13] Fransisca Natalia, Kurnia Abdurrahman Hariri, Surtika Ayumida, Muhamad 
Tabrani, "APLIKASI PROPAS

(PROGRAM PENGARSIPAN SURAT)

PADA KANTOR DESA

CIHAMBULU-SUBANG," J. Interkom,

vol. 14, no. 3, pp. 4-11, 2019, doi:

10.35969/interkom.v14i3.50. 